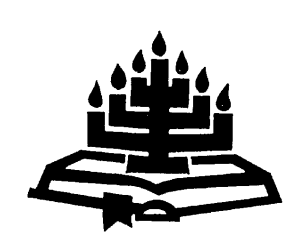

\title{
Doel van 1 en 2 Tessalonic enzen Meer overeenkomst dan verschil
}

\author{
Dirk Visser, Francois P. Viljoen \& Fika J. van Rensburg \\ Skool vir Bybelwetenskappe en Bybeltale \\ Potchefstroomse Universiteit vir $\mathrm{CHO}$ \\ POTCHEFSTROOM \\ E-pos: dirkvisser@hetnet.nl \\ sbbfpv@puknet.puk.ac.za \\ sbbjjjvr@puknet.puk.ac.za
}

\begin{abstract}
Purpose of 1 and 2 Thessa lonians. More similarities than differences

This article examines the purpose of 1 and 2 Thessalonians. In the first half of both letters Paul thanks God for the faith, love and hope of the Thessalonians. In 1 Thessalonians Paul expresses his love for the readers with the purpose of strengthening his relationship with them. In 2 Thessalonians, written shortly after 1 Thessalonians, he seemingly do not regard it as necessary to repeat the nature of this relationship with the Thessalonians. In his first letter he calls the Thessalonians to a life of sanctification. In 2 Thessalonians he did likewise in his exhortation to the busy bodies (3:11). In both letters Paul writes repeatedly and extensively about the parousia, especially in 1 Thessalonians 4:13-18; 5:1-11, and in 2 Thessalonians 1:5-10 and 2:1-12. However, Paul's intention in writing these passages is not to explain the nature of the parousia, but to emphasize the aspect of paraclesis from the perspective of the parousia.
\end{abstract}

\section{Opsomming}

Doel van 1 en 2 Tessalonisense. Meer ooreenkoms as verskil

In hierdie artikel word die doel van 1 en 2 Tessalonisense ondersoek. In die eerste helfte van albei briewe dank Paulus God vir die geloof, liefde en hoop van die Tessalonisense. In 1 Tessalonisense vermeld Paulus sy liefde vir die lesers om die verhouding tussen hom en hulle te versterk. In 2 Tessalonisense, wat kort daarna geskryf is, het hy dit kennelik nie nodig geag om die aard van sy verhouding met die Tessalonisense te herhaal nie. In 1 Tessalonisense roep hy die lesers op tot heiligmaking; in 2 Tessalonisense herhaal hy hy dit in sy oproep tot die "bemoeisiekes" (3:11). In albei 
briewe skryf Paulus herhaaldelik en uitvoerig oor die parousia (terugkeer van Jesus), veral in 1 Tessalonissense 4:13-18 en 5:1-11 en 2 Tessalonissense 1:5-10 en 2:1-12. Paulus het egter nie die briewe geskryf om die aard van die parousia te verduidelik nie, maar om die aspek van paraklese te benadruk vanuit die perspektief van die parousia.

\section{Probleemstelling}

Met welk doel werden 1 en 2 Tessalonicenzen geschreven? Waarom vond Paulus het nodig deze twee brieven kort na elkaar te schrijven, nadat Timoteüs de gemeente van Tessalonica had bezocht en met goede berichten was teruggekeerd? Het antwoord op deze vragen is van betekenis voor de uitleg van 1 en 2 Tessalonicenzen, ook in hun onderlinge relatie.

Uit het volgende overzicht blijkt dat de vraag naar het doel van 1 en 2 Tessalonicenzen nog niet bevredigend is beantwoord.

\section{Tessalonicenzen}

- Schubert (1939:24-36) leest 1 Tessalonicenzen als uiting van dank, waarbij hij de hoofdstukken 1-3 opvat als dé brief, met 4-5 als slotvermaningen.

- Johanson (1987:135) ontleent aan de structuur van de brief dat er sprake is van een ernstige situatie. Daar zou Paulus in 4:13-5:11 op ingaan, met name in 4:13-18.

- Marxsen (1979:26-29) denkt er ook zo over, maar ziet het fundamentele probleem verwoord in 1 Tessalonicenzen 5:1-11.

- Smith (1995:59-60) legt alle nadruk op troost als doel van 1 Tessalonicenzen, omdat hij de brief leest vanuit het thema scheiding, in de eerste plaats vanuit de scheiding die er tussen Paulus en de gemeente is.

- Cornelius (1998:70-71, 119) vat 1 Tessalonicenzen 3:11-12 en 5:23 op als formuleringen van het doel. Paulus wil de levens van de lezers transformeren, zodat zij leven naar de wil van God. Leven als christenen naar de nieuwe regels van de gemeenschap waartoe zij zijn gaan behoren, ziet zij bovendien als het (stilzwijgende) hoofddoel.

- Malherbe (2000:85-86) typeert de brief als een voorbeeld van pastorale parenese, met het oog op een situatie die volgens hem ernstiger is dan Smith denkt, maar minder ernstig dan Johanson en Marxsen denken. 


\section{Tessalonicenzen}

- Schubert, Johanson, Smith en Cornelius houden zich nauwelijks of niet met 2 Tessalonicenzen bezig. Volgens Schubert (1939:26-29) is de inhoud van de tweede brief voornamelijk dogmatisch en zijn daardoor dankzegging en doel van 2 Tessalonicenzen heel anders dan van 1 Tessalonicenzen. Dat 2 Tessalonicenzen een ander doel dient, is de gangbare opvatting.

- Volgens Marxsen (1982:41-56) is deze brief veel later door een pseudepigraaf geschreven, vooral vanwege onzekerheid over het tijdstip van de parousie. Het ongeregeld gedrag, waarvan 3:6-12 spreekt, zou met de parousie samenhangen.

- Menken (1994:43, 69-78) denkt ook aan een pseudepigraaf in later tijd, vanwege verschil in eschatologie, in toon, maar vooral in stijl. Het is zijn overtuiging dat het doel van de brief in 2 Tessalonicenzen 2 ligt en dat de inhoud van de andere hoofdstukken op dit hoofdstuk is betrokken.

- Holmes (1998:23) noemt drie redenen waarom Paulus 2 Tessalonicenzen schreef: hevige vervolging van de gemeente (1:3-12), een misverstaan van de dag des Heren (2:1-12) en het gedrag van de ongeregelden (3:6-15). Hij noemt 2:1-12 de belangrijkste reden van de brief, betrekt 1:3-12 op 2:1-12, maar het ongeregeld gedrag in 3:615 niet.

- Malherbe (2000:356-361) stelt dat in 2:1-12 wel een belangrijke reden ligt, maar dat in de exegese daar te veel nadruk op wordt gelegd. Naar zijn mening ligt de reden meer in de vervolgingen waaronder de gemeente lijdt (2 Tess. 1:4) en in het ongeregeld gedrag van sommigen in de gemeente (2 Tess. 3:11).

Deze korte weergave van opvattingen maakt duidelijk dat bij de uitleg van 1 Tessalonicenzen dikwijls wordt gedacht dat Paulus deze brief met één (hoofd)doel schreef: als uiting van dank (Schubert), vanwege de ernstige eschatologische situatie (Marxsen, Johanson), als troostbrief (Smith), om de lezers als leden van een nieuwe gemeenschap, de christelijke gemeente, te doen leven (naar de wil van God) (Cornelius) of als parenese (Malherbe).

Het doel van 2 Tessalonicenzen wordt geheel anders opgevat. Malherbe zoekt de reden voor 2 Tessalonicenzen vooral in de vervolgingen en het ongeregeld gedrag van sommigen. De meeste verklaarders zien het belangrijkste doel echter liggen in 2:1-12 (o.a. Marxsen, Menken, Holmes). De herhaalde dankzegging in 2 Tessalonicenzen wordt, mede daardoor, anders gelezen dan die in 1 Tessalonicenzen. 
Deze verschillende opvattingen in de bepaling van het doel van 1 en 2 Tessalonicenzen, ook in hun relatie tot elkaar, maakt nader onderzoek naar dat doel gewenst.

In dit onderzoek wordt ervan uitgegaan dat 1 en 2 Tessalonicenzen kort na elkaar geschreven zijn door Paulus (Silvanus en Timoteüs). Ze moeten worden uitgelegd als brieven, maar dan van een eigen karakter. Het zijn apostolische brieven, gericht aan een christelijke gemeente om met haar de nodige communicatie te onderhouden (zie Malherbe, 2000:95-96).

\section{Doel van 1 Tessalonic enzen}

Paulus was dankbaar voor de goede berichten waarmee Timoteüs vanuit Tessalonica tot hem terugkeerde. Toch wilde hij nog steeds zelf graag naar de gemeente terugkeren om te voltooien wat aan hun geloof ontbrak (1 Tessalonicenzen 3:10). Toen dat niet mogelijk bleek, zocht hij contact met haar door zijn brief. Daarin brengt hij in de eerste plaats én herhaaldelijk zijn dank aan God voor de gemeente tot uitdrukking (1:2-3; $2: 13$ en 3:9). Daarom mag de dankzegging gezien worden als het eerste doel van 1 Tessalonicenzen waardoor de hoofdstukken 1-3 worden gedomineerd. In deze hoofdstukken verwoordt Paulus ook hoe innig de band tussen hem en de gemeente is. Hij doet dat met het doel die band te versterken.

1 Tessalonicenzen 4-5 wordt soms opgevat als het belangrijkste gedeelte van de brief, waarin Paulus het onderwijs geeft dat nodig is om te voltooien wat nog aan het geloof van de gemeente ontbrak (zie Johanson, 1987:109-111). Dan zou 1 Tessalonicenzen 3:10 het (belangrijkste) doel van de brief onder woorden brengen. Aan de vraag of dit zo is, zal bijzondere aandacht worden besteed.

Toen Paulus in de gemeente was, had hij haar onderwezen over de wandel met God (1 Tess. 4:1-2). Dat parakletisch onderwijs herhaalt hij in 1 Tessalonicenzen 4-5 en spitst hij toe op de heiligheid. Dat dit een belangrijk doel van zijn onderwijs is, blijkt uit 3:11-12 en 5:23.

Het is de vraag hoe in dit verband 1 Tessalonicenzen 4:13-5:11 moet worden getaxeerd. Geeft Paulus in dit gedeelte eschatologisch onderwijs of moet het ook worden gelezen als paraklese, zoals uit 4:18 en 5:11 kan worden geconcludeerd?

Op basis van deze verkenning zullen achtereenvolgens de volgende aspecten worden behandeld: 
- De herhaalde dankzegging (2.1)

- Versterking van de band met de gemeente (2.2)

- Geen doel in 3:10 (2.3)

- De roeping tot heiligheid (2.4)

- Paraklese (2.5)

- De parousie als perspectief (2.6)

\subsection{De herhaalde dankzegging}

De herhaling van de dankzegging geeft aan 1 (en 2) Tessalonicenzen een eigen karakter, zowel vergeleken met de andere brieven van Paulus als met de Griekse briefstijl (zie Lambrecht, 2000:148).

Door de drie uitingen van dank in 1:2-3; $2: 13$ en $3: 9$ neemt in 1 Tessalonicenzen 1-3 de dankzegging een belangrijke plaats in. Toch kan niet worden gezegd dat dit gedeelte alleen dankzegging bevat, hetzij als het (voornaamste) doel van de brief (Schubert, 1939:184 en O'Brien, 1977:164-165), of als inleiding op het corpus van de brief (Bjerkelund, 1967:134).

De eerste dankzegging is in wezen beperkt tot 1 Tessalonicenzen 1:2-3. Paulus heeft 1:4-10 er echter zodanig mee verbonden dat het één lange zin is geworden, maar zonder dat dit gedeelte rechtstreeks tot de inhoud van de dank behoort (zie Wanamaker, 1990:49-50, 73). Inhoudelijk is ook 2:1-12 met 1:2-10 verbonden, maar behoort evenmin direct tot de inhoud van de dank.

In 2:13 volgt de tweede dankzegging. De verzen 2:14-16 zijn nauw met dit vers verbonden, maar hebben een eigen inhoud. Er is geen aanleiding 2:14-16 (Richard, 1995:111-112) of 2:13-16 (Boers, 1975/76:158) als een interpolatie op te vatten (zie Baarda, 1984:22-30).

Het gedeelte 2:17-3:8 is van dank doortrokken, maar heeft toch een eigen inhoud. Het geeft een bewogen terugblik op de tijd nadat Paulus uit Tessalonica had moeten vertrekken.

Uit $g \grave{\alpha} r$ in 3:9 blijkt dat Paulus met dit vers nauw aansluit bij het voorgaande. In 3:9 herhaalt hij met een retorische vraag zijn dank, waarna hij in 3:10 over zijn gebed voor de gemeente schrijft. Daarna besluit hij dit gedeelte van zijn brief in 3:11-13 met een uniek overgangsgedeelte (Wiles, 1974:68-71).

$\mathrm{Na}$ deze beknopte verkenning is de vaststelling op haar plaats dat de eerste dankzegging in overeenstemming is met de briefstijl in de oud- 
heid. De tweede en derde dankzegging doorbreekt echter die briefstijl en maakt 1 Tessalonicenzen tot een schrijven sui generis, waarin Paulus vóór alles laat weten dat hij God dankbaar is dat de verkondiging van het woord bij hen, ondanks de druk van buiten, volharding bewerkt (zie Baarda, 1984:27-33).

In 1 Tessalonicenzen 1-3 is de dank aan God een belangrijk thema (zie Holmes, 1998:80-81). Deze drie hoofdstukken zijn van die dank doortrokken. Ze bevatten echter tevens een persoonlijke verwoording van de relatie die tussen de apostel en de gemeente is ontstaan, vanaf zijn komst in Tessalonica tot het moment waarop hij 1 Tessalonicenzen schreef. Daarom is de typering van 1 Tessalonicenzen 1-3 als één lange dankzegging te eenzijdig.

De conclusie kan worden getrokken dat in 1 Tessalonicenzen (1-3) de dank aan God het eerste doel is.

\subsection{Versterking van de band met de gemeente}

Het is de vraag of 1 Tessalonicenzen 1:2-2:16 (Cornelius, 1998:78-80) of 1:2-3:13 (Johanson, 1987:163) als een captatio benevolentiae kan worden gelezen. Toch is die typering begrijpelijk omdat Paulus in het eerste gedeelte van de brief de goede relatie tussen hem en de gemeente onder woorden brengt. Smith (1995:53-54) benadrukt dat ook, maar typeert 1 Tessalonicenzen als troostbrief. Hij legt namelijk alle nadruk op het verdriet dat Paulus zou voelen door de scheiding tussen hem en de gemeente. De herhaalde dankzeggingen maken echter duidelijk dat de nadruk niet op dat verdriet ligt, maar op de blijdschap vanwege de goede berichten die Paulus van Timoteüs over de gemeente kreeg. Zijn vreugde brengt de apostel niet alleen in de drie dankzeggingen onder woorden, maar ook in zijn persoonlijke weergave van de korte geschiedenis van de gemeente. Hij roept in herinnering hoe de leden van de gemeente door zijn apostolische arbeid tot geloof kwamen. Van Timoteüs heeft hij gehoord dat ze ondanks de verdrukkingen in het geloof hebben volhard en navolgers van Paulus en van de Here zijn geworden. Dat vervult de apostel met grote dankbaarheid. Het versterkt het verlangen en het gebed om hun aangezicht te mogen zien. Zo brengt Paulus in 1 Tessalonicenzen 1-3 zijn liefde voor de gemeente onder woorden, waarmee hij de broederband wil aanhalen (Holmes, 1998:23).

Hieruit mag de conclusie worden getrokken dat Paulus 1 Tessalonicenzen (1-3) ook schreef met het doel om de band met de gemeente te versterken. 


\subsection{Geen doel in 1 Tessalonic enzen 3:10}

In de exegese van 1 Tessalonicenzen (4-5) speelt 3:10 een belangrijke rol. Dat vers zou duidelijk maken dat het belangrijkste doel van 1 Tessalonicenzen is om aan te vullen wat aan het geloof van de lezers ontbrak. Dat zou dan in 1 Tessalonicenzen 4-5 aan de orde komen. Toch is het de vraag of zo aan 3:10 recht wordt gedaan. Is het wel zo duidelijk wat aan het geloof van de Tessalonicenzen ontbreekt?

Uit 1 Tessalonicenzen 4:1-12 blijkt dat Paulus in die gedeelten een herhaling en voortzetting geeft van het onderwijs dat hij al aan de lezers gaf. De vermaningen in 5:12-22 zijn beknopt en weinig concreet, zodat er het meest voor te zeggen valt dat het in dit gedeelte om algemene vermaningen gaat (zie Best, 1972:223).

In 4:13-5:11 is Paulus uitvoerig. Daarom valt het eerst aan dit gedeelte te denken als er iets ontbrak aan het geloof van de Tessalonicenzen. Het probleem zou dan in hun toekomstvisie hebben gelegen. Daarom zou de brief zo'n sterk eschatologisch accent hebben gekregen en bovendien in 4:13-18 en 5:1-11 twee uitvoerige eschatologische passages kennen. In 4:13-18 zou Paulus nader onderwijs hebben gegeven over het lot van de ontslapenen. Anderen denken dat (ook) onderwijs aangaande het tijdstip van de parousie nodig was. Daarom zou Paulus 5:1-11 hebben geschreven (zie Roosen, 1971:80-81). Daarbij rijst de vraag welk probleem het meest urgent was (zie Johanson, 1987:135 en Marxsen, 1979:2629).

Uit 5:1 mag worden geconcludeerd dat 5:1-11 niet gaat over onzekerheid inzake het tijdstip van de parousie (zie Holtz, 1990:210). Dat blijkt ook uit de nadruk waarmee in deze passage de leden van de gemeente kinderen van het licht en van de dag worden genoemd, die niet door de dag des Heren zullen worden overvallen (5:4-5). Wel wordt op hen een appèl gedaan wakker en nuchter te zijn tot die dag, waarop zij de zaligheid zullen verkrijgen (5:6-9). Uit 5:11 blijkt dat Paulus daarmee onderstreept wat in de gemeente al bekend is en leeft. Hij sluit (vooral in 5:10) daarbij aan bij 4:13-18.

Betekent dit dat Paulus in 1 Tessalonicenzen 4:13-18 schreef wat er ontbrak aan het geloof van de Tessalonicenzen? In 4:13 lijkt Paulus echter te zeggen dat er iets mis is met hun hoop. Vers 3:6 lijkt dat te versterken. Daar staat dat Timoteüs een goede tijding bracht over het geloof en de liefde van de gemeente, maar haar hoop niet noemt.

In 3:10 zegt Paulus echter niet dat er iets aan hun hoop ontbreekt, maar aan hun geloof. Bovendien spreekt hij in 1:3 net zo positief over hun hoop als over hun geloof en liefde; zo ook in 5:8. Evenals uit 5:1-11 blijkt 
uit 1:10 dat er niets mis was met hun toekomstverwachting. Het zou merkwaardig zijn als dat in 4:13-18 wel zo was. In dit gedeelte gaat het echter niet over een verkeerde hoop. De vraag wordt beantwoord of de gestorven gelovigen, vergeleken met de levende, bij de parousie in het nadeel zullen zijn. Het gaat dus om een heel speciale en beperkte problematiek die wel met de hoop samenhangt, maar er niet mee kan worden geïdentificeerd.

In 3:12 schrijft Paulus dat hij God bidt of de Here groeiende en overvloedige liefde aan de Tessalonicenzen wil geven, zowel tot elkaar als tot allen. Daaruit zou men kunnen concluderen dat het gebrek in hun geloof lag in gebrek aan liefde. In 1:3 en 3:6 geeft Paulus echter een goed getuigenis van hun liefde. En in 4:9-10, waar de Tessalonicenzen worden aangespoord elkaar méér lief te hebben, schrijft hij eerst dat ze van God geleerd hebben elkaar lief te hebben. De liefde ontbreekt dus niet; in 3:12 bidt Paulus om toename van de liefde.

Ten slotte valt te constateren dat Paulus positief over het geloof van de lezers spreekt, in 1:3-8; 2:13-14 en 3:6. Daarop gelet, wekt 3:10 verbazing, ook omdat Paulus niet concretiseert wat dan aan hun geloof ontbrak. Dat leidt tot de gedachte dat het Paulus blijkbaar nog steeds dwars zat dat hij zijn verblijf in Tessalonica moest afbreken. Daardoor had hij de gemeente niet dát onderwijs kunnen geven dat zij naar zijn overtuiging nodig had. In dit verband is sprekend dat er staat dat Paulus hun aangezicht wilde zien om te voltooien wat aan hun geloof ontbrak. Hij verlangde er sterk naar hen persoonlijk te ontmoeten en nader te onderwijzen tot versterking van hun prille geloof. Dat schrijft hij niet alleen in vers 10, maar ook in 11. Hij bidt vurig dat God de weg tot hen baant. Zo moeten we 3:10 in de context verstaan.

Deze uitleg leidt tot de conclusie dat 3:10 niet bedoeld is om een doel voor 1 Tessalonicenzen (4-5) aan te geven.

\subsection{De roeping tot heiligheid}

Om te bepalen waartoe Paulus 1 Tessalonicenzen 4-5 schreef, is zijn gebed om de (onberispelijkheid in) heiligheid bij de parousie in 3:13 én in $5: 23$ van belang. Die heiligheid is in 4:1-5:22 een belangrijk thema (zie $4: 3,7)$. Paulus wil bereiken dat zijn lezers (blijven) wandelen naar de wil van God. Dat is een stated purpose (Cornelius, 1998:119).

Paulus stelt het thema van de heiligheid niet aan de orde, omdat er een concrete reden was om dat te doen. Hij wilde de jonge gemeente met pastorale intuïtie waarschuwen voor de potentiële gevaren waaraan zij blootstond (Johanson, 1987:114-116). Bovendien wilde hij hen, die met 
verdrukking te maken hebben, aanmoedigen om op de ingeslagen weg voort te gaan. Hij spoort hen aan Gode waardig te blijven wandelen.

Heiligheid is het doel van het geloofsleven. Daarom herhaalt en onderstreept Paulus de roeping tot heiligheid.

\subsection{Paraklese}

Een tweede doel dat Paulus met 1 Tessalonicenzen 4:1-5:22 beoogt, is paraklese. Het werkwoord p a r a ka I Éw gebruikt hij in dit gedeelte vijf keer (4:1, 10 en 18 en 5:11 en 14). In de hele brief komt het acht keer voor, terwijl in 2:3 het zelfstandig naamwoord pa r ák I h s i s wordt gebruikt.

Malherbe (2000:81-85) typeert 1 Tessalonicenzen als parenese; in de nieuwtestamentische wetenschap de gangbare aanduiding voor de vermanende gedeelten. Het is echter opmerkelijk dat bij Paulus het werkwoord para in $\varepsilon^{\prime}$ niet voorkomt, maar parakal $\varepsilon^{\prime} w$ meer dan vijftig keer. Zou het daarom niet meer voor de hand liggen om met Roosen (1971:83) te spreken van paraklese in plaats van paranese?

Botha en Van Rensburg (1993) hebben onderzocht welke van deze termen het beste voor de nieuwtestamentische moral exhortation kan worden gebruikt. Hun conclusie dat de verscheidenheid in het nieuwtestamentische spreken inzake moral exhortation gemakkelijk uit het oog kan worden verloren als dit spreken onder één term wordt samengevat, verdient bijval (Botha \& Van Rensburg, 1993:50).

In aansluiting op dit onderzoek kan 1 Tessalonicenzen beter niet als een brief in het parenetische of het parakletische genre worden getypeerd. Paraklese speelt in deze brief echter wel een belangrijke rol. In 2:12 herinnert Paulus de lezers aan zijn paraklese om tot de komst van het Koninkrijk Gode waardig te blijven wandelen. In 1 Tessalonicenzen herhaalt hij zijn appèl op hen om in hun goede wandel te blijven volharden tot de parousie. Dat parakletisch onderwijs geeft hij vooral in $4: 1-5: 22$.

Om de bedoeling van Paulus met dat onderwijs te verstaan is het van belang erop te letten dat hij in 4:1 met nadruk schreef dat de wandel van zijn lezers al goed was. Daarom gaat het niet om een vermaning, maar om een aansporing en bemoediging. Dat spreekt te meer daar 4:1-2 de inleiding op de tweede helft van de brief is (Malherbe, 2000:217).

De gedachte dat de lezers reeds doen wat Paulus van hen vraagt, wordt herhaald in 4:10 en 5:11. Daarom ligt het niet voor de hand in 5:11 de werkwoordsvorm pa r a ka l e it e met vermanen te vertalen zoals de NBG- 
vertaling (1951) doet, maar met bemoedigen. Gelet op de inhoud van 4:13-17 lijkt ook in 4:18 vermanen de bedoeling van Paulus niet goed weer te geven. Daar valt eerder aan vertroosten te denken, maar ook het aspect van bemoedigen is aanwezig.

Volgens Smith (1990:110) is de hele brief een troostbrief, omdat hét thema scheiding is. De argumenten die hij daarvoor gebruikt, overtuigen niet. Hij maakt echter wel attent op het feit dat Paulus deze brief schreef, omdat hij van de gemeente gescheiden was. Daarom zond hij eerst Timoteüs en daarna 1 Tessalonicenzen tot hen met het doel de gemeente te versterken en te bemoedigen in haar geloof. Hij spoort haar aan de goede wandel voort te zetten en te intensiveren. In 4:18 en 5:11 geeft hij aan die paraklese een bijzonder accent, doordat hij zijn lezers opwekt met zijn woorden aan elkaar paraklese te geven (Smith, 1990:110).

Uit de goede wandel van de lezers mag worden geconcludeerd dat de zaken die Paulus in 1 Tessalonicenzen 4:1-5-22 aan de orde stelt, niet dringend waren. Als dat wel zo was, had Paulus ze stellig eerder een plaats in de brief gegeven. Dat geldt zeker voor 4:3-12 en 5:12-22 (zie Johanson, 1987:114-116), maar ook voor het uitvoeriger en concreter gedeelte 4:13-5:11 (zie Cornelius, 1998:91).

Paraklese, vooral in de zin van bemoediging, is een belangrijk doel van 1 Tessalonicenzen, met name van 4:1-5:22. Zoals uit 4:18 en 5:11 blijkt, geldt dat ook voor de zogenoemde eschatologische gedeelten, 4:13-18 en $5: 1-11$.

\subsection{De parousie als perspectief}

Omdat 1 Tessalonicenzen 4:13-18 en 5:1-11 uitvoerig over de parousie gaan, worden deze eschatologische passages dikwijls als het belangrijkste doel van de brief opgevat (zie Marxsen, 1979:26-29 en Johanson, 1987:135). Die visie lijkt te worden ondersteund door de vele eschatologische noties in de brief buiten 4:13-5:11 om, in 1:3, 9-10; 2:12; 19-20; 3:13 en 5:23. Daarom lijkt 1 Tessalonicenzen door en door eschatologisch (zie De Boor, 1975:14).

Toch heeft Richard (1995:258-266) gelijk dat 1 Tessalonicenzen verkeerd wordt gelezen als alle aandacht uitgaat naar het eschatologisch karakter. Dat geldt ook voor 4:13-5:11, een gedeelte dat Richard in relatie tot 4:3-12 leest als een antwoord op de vraag hoe christenen in een niet-christelijke wereld moeten leven. Dat is een belangrijk element dat in de uitleg van deze gedeelten weinig of geen aandacht krijgt.

Een ander belangrijk element bleek in 2.5. 1 Tessalonicenzen 4:13-5:11 is een onderdeel van 4:1-5:22 en geschreven om de gemeente aan te 
sporen in alle omstandigheden de goede weg te (blijven) gaan (zie Smith, 1995:90-91).

Veel exegeten vatten 1 Tessalonicenzen 4:13-5:11 op als onderwijs over de parousie (zie Lambrecht, 2000:172-173). Daarbij komt de overtuiging dat er in 4:13-18 sprake is van een intensieve Naherwartung (Malherbe, 2000:270-271). Ook dispensationalisten kennen een vorm van Naherwartung (Fijnvandraat \& Medema, 1992:70).

De gedachte aan Naherwartung is ontleend aan 1 Tessalonicenzen 4:15 en 17, waar Paulus spreekt van: ijme is 0 i $z \hat{n}$ tejs o i per il eipómenoi tot de parousie. Hoffmann (1966:220-228) leest dat er ook in, maar constateert niettemin terecht dat in deze verzen de nadruk ligt op $0 \dot{v}$ mì f q áw men. Paulus kende geen Naherwartung in de zin dat hij de komst van de Here meteen verwachtte (Soforterwartung). Hij verwachtte Hem steeds (Stetserwartung). De typering is ontleend aan Erlemann (1995: 414).

Het gaat Paulus er in 4:13-18 niet om de gemeente (opnieuw) voor te houden dat zij de parousie zullen meemaken. Hij gaat in op de vraag die in de gemeente leeft hoe het de gestorven gelovigen bij de parousie zal vergaan. Op dat punt vertroost hij hen. Hij verzekert hen dat de ontslapenen niet zullen worden achtergesteld. Zij zullen bij de komst des Heren eerst opstaan, waarna alle gelovigen met de Here zullen worden verenigd om altijd met Hem te zijn (4:17). Zo geeft hij woorden van vertroosting met het oog op de ontslapenen. Hij geeft paraklese met de parousie als perspectief.

Datzelfde perspectief komt ook in 5:10 naar voren. In 2.3 bleek dat het in 1 Tessalonicenzen 5:1-11 niet gaat over het tijdstip van de dag des Heren. De kinderen van het licht worden tot de dag des Heren met de nacht geconfronteerd in verdrukking en verleiding. Daarom is blijvende nuchterheid en waakzaamheid geboden (5:6-8). In 5:1-11 staat de gedachte centraal dat de gelovigen voor de komst van Christus gereed moeten zijn (zie Lövestam, 1963:51-58).

Dat betekent dat het in 5:1-11 niet gaat om de parousie, maar om paraklese in het perspectief van de parousie. Die paraklese klinkt niet alleen in 4:13-5:11, maar in heel 4:1-5:22 (zie Smith, 1995:90). Uiteraard geeft Paulus in 4:13-5:11 ook onderwijs over de parousie. Zijn doel is echter om ook met deze gedeelten paraklese te geven in het licht van de parousie. 


\section{Doel van 2 Tessalonicenzen}

Uit de inhoud van de dankzegging in 2 Tessalonicenzen 1:3-4 en 2:13 blijkt dat de dankbaarheid van Paulus niet is verminderd. De band met de gemeente blijkt nog steeds sterk te zijn. De apostel had twee redenen om 2 Tessalonicenzen te schrijven: hij wilde de gemeente bemoedigen vanwege de toegenomen vervolgingen (1:4); hen die zich ongeregeld gedroegen (3:6-12) wilde hij vermanen (zie Malherbe, 2000:351). Daaruit blijkt dat ook in deze brief paraklese een belangrijk doel is. Omdat 2 Tessalonicenzen in 1:5-10 en 2:1-12 uitvoerige eschatologische passages bevat, moet worden onderzocht of die in deze brief een zelfstandig doel dienen, of dat het ook hier gaat om de parousie als perspectief. Achtereenvolgens zullen de volgende aspecten worden behandeld:

- De herhaalde dankzegging (3.1)

- Versterking van de band met de gemeente (3.2)

- Paraklese (3.3)

- Vermaning van de ongeregelden (3.4)

- De parousie als perspectief (3.5)

\subsection{De herhaalde dankzegging}

In 2 Tessalonicenzen is het opmerkelijk dat 2:13 een tweede dankzegging kent, net als in 1 Tessalonicenzen. Even opmerkelijk zijn de verschillen tussen de dankzeggingen in 1 en 2 Tessalonicenzen. Zo spreekt Paulus in 1 Tessalonicenzen 3:9 nog een derde keer zijn dank uit. De dankzeggingen in 2 Tessalonicenzen kennen, vergeleken met 1 Tessalonicenzen, de toevoegingen $\dot{\alpha} \mathrm{f}$ e $\mathrm{l}$ l o men (2 Tessalonicenzen 1:3; 2:13) en kaq $\omega$ s äxión غ̇s tin (2 Tessalonicenzen 1:3). Die lijken deze dankzeggingen formeler en koeler te maken. Dat is niet het geval als deze toevoegingen liturgische formuleringen zijn (zie Bruce, 1982:143). Bovendien geeft, vergeleken met de dankzeggingen in 1 Tessalonicenzen, de toevoeging van "broeders" in 2 Tessalonicenzen 1:3 en van "door de Here geliefde broeders" in 2:13 aan deze dankzeggingen een toon van hartelijkheid en warmte.

Verder valt het op dat de inhoud van de dankzeggingen in 2 Tessalonicenzen 1:3-4 op belangrijke punten anders is dan in 1 Tessalonicenzen 1:2-3. Zo ontbreken bij geloof en liefde in 2 Tessalonicenzen 1:3-4 de toevoegingen "werk" en "inspanning". In plaats van over de volharding der hoop wordt er slechts over volharding gesproken. Daarna volgt nog de toevoeging: over hun geloof in al hun vervolgingen en verdrukkingen. 
Ten slotte verschilt 1 Tessalonicenzen 2:13 inhoudelijk van 2 Tessalonicenzen 2:13 doordat in de laatste tekst de nadruk valt op Gods verkiezing tot behoud. Dat correspondeert met 1 Tessalonicenzen 1:4, terwijl 1 Tessalonicenzen 2:13 gaat over het gepredikte woord dat de Tessalonicenzen hebben aangenomen.

Al deze verschillen maken duidelijk dat (de dankzeggingen in) 2 Tessalonicenzen geen slaafse kopie van 1 Tessalonicenzen zijn, zoals Bailey (1978/79:136) denkt. Paulus zelf schreef 2 Tessalonicenzen, omdat hij dat nodig achtte vanwege veranderde omstandigheden (zie Malherbe, 2000:368-369).

Veel verklaarders lezen 2 Tessalonicenzen 1:3-12 als een inleidende dankzegging (zie O'Brien, 1977:167-168). Het nieuwe gedeelte zou beginnen in 2:1 met woorden als in 1 Tessalonicenzen 4:1, waar ook een nieuw gedeelte begint (zie Bjerkelund, 1967:137-139).

Dit argument is niet zo sterk als het lijkt. De dankzegging is in wezen beperkt tot 1:3-4. In 1:5-10 wordt de gemeente bemoedigd te volharden in de verdrukkingen (zie Verhoef, 1998:252). In 1:11-12 is er wel sprake van een zekere afronding, maar 2:1 en 2:8-10 grijpen inhoudelijk terug op 1:5-12. Op deze overeenkomsten maakt Du Preez (1981:117) attent, alsook op de overige overeenkomsten tussen 2 Tessalonicenzen 1:3-12 en 2:1-17.

Toch meent Bjerkelund (1967:137-139) dat Paulus in 2:1 met een nieuw gedeelte begint dat 2:1-12 omvat, waarin hij een eschatologische dwaling moest bestrijden. De verwijzing van Bjerkelund naar 1 Tessalonicenzen 4:1 maakt zijn uitleg om twee redenen problematisch. In de eerste plaats is er een sterke overeenkomst in woordkeus, die in 1 Tessalonicenzen 4:1 wijst op de goede relatie tussen Paulus en de gemeente. Dat is ook de opvatting van Bjerkelund. Dat maakt het twijfelachtig dat er in 2 Tessalonicenzen 2:1 wordt gereageerd op een ernstige situatie. In de tweede plaats begint 2 Tessalonicenzen 3:1 op een vergelijkbare wijze als 1 Tessalonicenzen 4:1. De tweede helft van de brief kan dus net zo goed met 2 Tessalonicenzen 3:1 beginnen. Dat wordt onderstreept door het feit dat 2:16-17 een afsluiting vormt die te vergelijken is met 1 Tessalonicenzen 3:11-13.

Dat leidt tot de gedachte dat de eerste helft van 2 Tessalonicenzen dezelfde structuur heeft als die van 1 Tessalonicenzen. Die gedachte wordt versterkt door de constatering dat 2:1-12 met 2:13-17 een eenheid vormt (zie Giblin, 1967:43-48 en Menken, 1994:71-73). De eenheid komt het sterkst openbaar tussen 2:10-12 en 13-14, waarin dezelfde tegenstelling tussen de ongelovigen die verloren gaan en de gelovigen die de 
heerlijkheid van onze Here Jezus Christus zullen verkrijgen, wordt geschetst als in 1:5-12.

Verder kent 2 Tessalonicenzen 2:16-17 overeenkomst met 1:3-10 (zie Hughes, 1989:57-61) en met 1:11-12 (zie Du Preez, 1981:117).

Deze beknopte analyse leidt tot de conclusie dat 2 Tessalonicenzen 1:32:17 één geheel is, omraamd en gekenmerkt door de herhaalde dankzegging, zoals 1 Tessalonicenzen 1:2:3-13. Evenals in 1 Tessalonicenzen is in 2 Tessalonicenzen de dank aan God een belangrijk doel.

\subsection{Versterking van de band met de gemeente}

Een belangrijk verschil tussen 1 en 2 Tessalonicenzen is dat in de tweede brief weinig uit 1 Tessalonicenzen 1-3 terugkeert, zelfs niet Paulus' verlangen naar de gemeente terug te keren (1 Tessalonicenzen 3:11). Dat is voor Marxsen (1982:36-37) een bewijs dat 2 Tessalonicenzen niet door Paulus geschreven kan zijn. Hij ziet dat onderstreept door een ander gebruik van het werkwoord k a t e u q ún a i uit 1 Tessalonicenzen 3:11 in 2 Tessalonicenzen 3:5. Dat verschil pleit echter voor Paulus als auteur. Kort na 1 Tessalonicenzen hoefde de apostel zijn liefde tot de gemeente en zijn verlangen tot haar terug te keren niet te herhalen.

Zijn band met de gemeente brengt hij indirect tot uitdrukking door in 1:34 te danken voor de toename van haar geloof en liefde en voor haar volharding in de verdrukkingen. De band blijkt ook uit zijn grote betrokkenheid, als hij schrijft waarop het voor hem en zijn lezers (en hun verdrukkers) uitloopt (1:5-12 en 2:10-14). Verder vuurt hij hen aan in hetzelfde spoor verder te gaan (2:15), in het vertrouwen dat zij dat (zullen) doen (3:5). Hij vermaant (sommigen in) de gemeente vanwege de ongeregeldheid (3:6-15). En hij bidt voor hen tot God om hen te bemoedigen en te versterken. Die versterking komt met zoveel woorden aan de orde, maar de versterking van de band met de gemeente verwoordt Paulus niet direct zoals in 1 Tessalonicenzen 1-3.

\subsection{Paraklese}

2 Tessalonicenzen heeft een parakletisch doel, net als 1 Tessalonicenzen. Malherbe (2000:359, 361) constateert deze overeenkomst ook, maar spreekt van parenese (zie 2.5). In 2 Tessalonicenzen staan de woorden parakal ćs a i en par ákl hs i s in de centrale tekst 2:16-17. Het ligt voor de hand deze woorden op dezelfde wijze te vertalen, vanwege het verband met bemoediging en bemoedigen. Die bemoediging heeft de gemeente niet nodig vanwege eschatologische nood waarin zij verkeert, zoals Wanamaker (1990:271) denkt. Met Holmes (1998:255) valt te 
zeggen dat het gaat om bemoediging vanwege de vervolgingen en verdrukking waaronder de gemeente lijdt (1:4). Vanaf 1:5 geeft Paulus zijn lezers bemoediging die met zijn gebed in 2:16-17 tot een afronding komt. Zij vindt haar basis in de bemoediging die de Here door zijn genade zelf aan de gemeente heeft gegeven. Op grond daarvan hebben de lezers goede hoop. Het mag hun moed geven om in de verdrukkingen te volharden. Zo geeft Paulus in 2 Tessalonicenzen 1-2 aan de gemeente paraklese.

Als conclusie kan worden getrokken dat in 2 Tessalonicenzen paraklese een belangrijk doel is, net als in 1 Tessalonicenzen.

\subsection{Vermaning van de ongeregelden}

De aansporing tot heiligheid komt in 2 Tessalonicenzen veel beknopter aan de orde dan in 1 Tessalonicenzen. In 2:13 stipt Paulus de heiliging slechts aan, terwijl in 2:17 de zaak aan de orde komt als het gaat over alle goed werk. Deze tekst kan ook worden betrokken op het ongeregeld gedrag van sommigen die geen werk verrichten, maar bezig zijn met wat geen werk is (2 Tessalonicenzen 3:6-12).

Met anderen legt Menken (1994:133) een relatie tussen het ongeregeld gedrag en een gerealiseerde eschatologie, waarvan in 2:2 sprake zou zijn. Hij voegt eraan toe dat dit niet te bewijzen is. Er zijn wel argumenten tegen de relatie tussen eschatologie en de ongeregeldheid. Uit 1 Tessalonicenzen 2:9 en 4:9-12 blijkt dat Paulus al nadruk had gelegd op de noodzaak te werken, voordat zich een verkeerde eschatologie kon ontwikkelen (zie Malherbe (2000:360-361). Bovendien wordt er geen relatie met de eschatologie gelegd, maar met het werk van Paulus (zie Holmes, 1998:270).

In 1 Tessalonicenzen 4:11-12 en 5:14 hoefde de ongeregeldheid slechts te worden aangestipt. Paulus had echter gehoord dat later de ongeregeldheid was toegenomen (2 Tessalonicenzen 3:11). Daarom vermaande Paulus zijn lezers in 2 Tessalonicenzen 3 scherp en met het gezag van de Here Jezus Christus om rustig bij hun werk te blijven en hun eigen brood te eten. Deze uitvoerige vermaning aan de (ongeregelden in de) gemeente is een belangrijk doel van 2 Tessalonicenzen. Dat is een verschil met de beknopte vermaning in 1 Tessalonicenzen.

\subsection{De parousie als perspectief}

In 2 Tessalonicenzen lijkt het uitvoerige eschatologische onderwijs in 1:5-10 en 2:1-12 de eigenlijke reden voor deze brief te zijn. Volgens veel verklaarders is er sprake van een eschatologische dwaalleer, die in 2:1- 
12 wordt bestreden (zie Trilling, 1980:45; Marxsen, 1982:41-55; Menken, 1994:69-78 en Holmes, 1998:270).

Bolkestein (1974:177) ziet die verklaring ondersteund door het ontbreken in 2 Tessalonicenzen 1:4 van het woord hoop uit de trias, geloof, liefde en hoop (1 Tess. 1:3 en 5:8). Volgens hem zou dat betekenen dat men tot de overtuiging was gekomen dat de hoop was vervuld. Maar 2 Tessalonicenzen 1:5-10 en 2:1-12 zijn geen concrete reactie op die overtuiging. In 2 Tessalonicenzen 1:4 sluit Paulus wel aan bij de trias van 1 Tessalonicenzen 1:3. Van de uitdrukking "de volharding van uw hoop" gebruikt hij de volharding. Dat concrete aspect van de hoop paste bij de situatie van de gemeente (zie Roosen, 1971:134).

Paulus dankte voor hun volharding. Trilling (1980:45) is echter van mening dat de dankzegging in 1:3-4 formeel is, omdat zij volgens hem niet past bij de ernstige situatie die zich voordeed door een eschatologische dwaalleer. Dat is voor hem een bewijs dat de brief veel later door een pseudepigraaf is geschreven. Tegen dat laatste is met Best (1972:251) in te brengen dat van een pseudepigraaf te verwachten viel dat hij de hele trias, in de unieke vorm van 1 Tessalonicenzen 1:3, zou hebben overgenomen. De vrije omgang met de trias is een belangrijk argument voor Paulus als auteur van 2 Tessalonicenzen. De hartelijke elementen in de dankzegging maken duidelijk dat er op dit punt geen sprake is van een ernstige situatie.

De situatie is ernstig voor de gemeente vanwege de vervolgingen waaronder zij lijdt. Maar Paulus troost haar met het uitzicht op de dag des Heren. Trilling (1980:66-68) erkent dat om die reden 2 Tessalonicenzen 1:5-10 is geschreven, maar noemt de passage beneden Paulus' niveau en zwart-wit. In 1 Tessalonicenzen 2:14-16 schrijft Paulus niet minder zwart-wit over Gods toorn; zie ook 1 Tessalonicenzen 1:10; 4:6 en 5:9. In 2 Tessalonicenzen doet hij dat, omdat hij wil benadrukken dat Gods oordeel bij de parousie voor de gemeente het einde van alle verdrukkingen betekent. Deze passage is derhalve primair niet geschreven om informatie over (Gods oordeel bij) de parousie te geven, maar om vanuit de komst des Heren de gemeente te bemoedigen om te blijven volharden (zie Richard, 1995:321).

Vanuit die bedoeling is het niet juist 1:5-10 te lezen als een voorbereiding op het eschatologisch hoofdthema in 2:1-12 (zo Wanamaker, 1990:49-50). In 2:1-12 zet Paulus zijn onderwijs voort dat de gemeente nodig heeft om te blijven volharden. Hij herhaalt zijn boodschap van oordeel en heerlijkheid bij de komst van de Here. Maar in 2:3-7 wijst hij er ook op dat voor de parousie de tijden nog zwaarder zullen worden door de afval en de openbaring van de wetteloze. Daarom waarschuwt 
Paulus in 2:2-3a zijn lezers zich op geen enkele wijze te laten misleiden. Maar bovenal dankt hij God, zowel voor de toename van hun geloof en liefde en hun volharding (1:3-4) als voor hun toekomstig behoud (2:1314).

Vers 2:2b lijkt deze uitleg tegen te spreken, omdat Paulus met $\dot{\omega}$ ót i

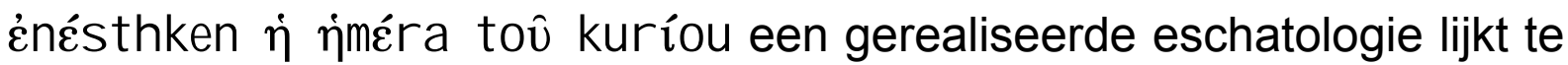
verwoorden. Om zo'n eschatologie te bestrijden is de inhoud van 2:3-8 echter niet geschikt (zie Bruce, 1982:165-166).

Anderen denken dat Paulus eschatologisch onderwijs moest geven omdat 1 Tessalonicenzen, met name 5:1-11, verkeerd was opgevat (Malherbe, 2000:428-430). Holmes (1998:29) voegt daar echter aan toe dat in duisternis is gehuld wat de Tessalonicenzen op dit punt precies geloofden. Die toevoeging maakt in alle scherpte duidelijk hoe belangrijk de exegese van $2: 2 b$ is.

Dit vers moet worden gelezen in verband met 2:2a en $3 a$. In deze verzen schrijft Paulus niet dat de lezers misleid zijn, maar in de vorm van een broederlijk verzoek waarschuwt hij hen dat ze daarvoor moeten oppassen vanwege hun moeilijke situatie. $\mathrm{Na}$ de bemoediging met de komst des Heren in 1:5-12 moeten zij niet de verkeerde conclusie trekken dat de dag des Heren er al (bijna) is. Dat Paulus op die manier de gemeente aanspoort te blijven volharden, wordt niet alleen onderstreept door de dankzeggingen in 1:3-4 en 2:13, maar blijkt ook uit het feit dat Paulus in 2:3-7 zo beknopt kon zijn, omdat zijn lezers de dingen die hij schrijft, reeds wisten (2:5-6). Als er sprake van een eschatologische dwaling was geweest, had Paulus daar duidelijk op moeten ingaan. Voor de Tessalonicenzen was Paulus duidelijk genoeg, omdat er geen sprake van een dwaling was (zie Wanamaker, 1990:249).

De juistheid van deze uitleg blijkt ook uit 2:1, een vers dat in de exegese stiefmoederlijk wordt bedeeld. Dat komt door de opvatting dat 2:2b het belangrijkste onderwerp van de brief bevat (Menken, 1994:97). Daardoor krijgt 2:1 het karakter van een pro-memoriepost (zie Von Dobschütz, 1909: 264 en Kramer, 1992:54). Met dit vers grijpt Paulus echter niet alleen terug op 1 Tessalonicenzen 4:17 en 5:10, maar ook op 2 TessaIonicenzen 1:7 en 10-12, terwijl 2:13-14 dezelfde inhoud hebben. Dit vers kan derhalve een scharniervers worden genoemd, nauw verbonden met de dankzeggingen in 1:3-4 en $2: 13-14$, dat de bedoeling van de zogenaamde eschatologische passages in 1:5-10 en 2:1-12 samenvat (zie Visser, 1994:196). Bij de parousie loopt het uit op de vereniging met de Here. Tot die dag is er volharding in de verdrukkingen nodig, ook als die door de afval en de openbaring van de wetteloze zwaarder zullen worden. De gemeente mag zich bemoedigd weten, omdat zij volhardt, 
maar vooral door het uitzicht op haar vereniging met de Here (2:1). Dan zullen zij in de heerlijkheid delen (1:10-12 en 2:13-14). Dat is het uitzicht op de parousie, waarmee Paulus zijn lezers bemoedigt. Hij geeft die bemoediging in het perspectief van de parousie.

\section{Sa menvatting en conclusie}

Wie 1 en 2 Tessalonicenzen met elkaar vergelijkt, wordt getroffen door de sterke overeenkomst in inhoud en doel.

In beide brieven wordt de eerste helft sterk bepaald door dank aan God, omdat de Tessalonicenzen staande zijn gebleven in het geloof (1 Tessalonicenzen 3:8); zij volharden in de verdrukkingen (2 Tessalonicenzen 1:4).

In 1 Tessalonicenzen 1-3 brengt Paulus de innige band die hij met de gemeente heeft uitvoerig onder woorden, met de bedoeling de band te versterken. Omdat Paulus 2 Tessalonicenzen kort na 1 Tessalonicenzen schreef, herhaalde hij dat niet, maar bracht zijn band met de gemeente indirect ter sprake in het positieve getuigenis dat hij van de gemeente geeft, vooral in 1:3-4.

In 1 Tessalonicenzen 4:1-5:22, omraamd door 3:11-13 en 5:23-24, ligt grote nadruk op de roeping tot heiligheid in het licht van de parousie. In 2 Tessalonicenzen wordt het aspect van de heiligheid slechts aangestipt; zakelijk komt zij toegespitst aan de orde in de vermaning aan de ongeregelden in 2 Tessalonicenzen 3.

In beide brieven neemt de paraklese een belangrijke plaats in. Dat geldt met name voor 1 Tessalonicenzen 4:1-5:22 en 2 Tessalonicenzen 1:32:17, inclusief de zogenaamde eschatologische gedeelten, 1 Tessalonicenzen 4:13-18 en 5:1-11 en 2 Tessalonicenzen 1:5-10 en 2:1-12.

De eschatologische boodschap in deze gedeelten is in wezen gelijk. Bij de parousie zullen alle gelovigen met de Here verenigd worden ( 1 Tessalonicenzen 4:17 en 5:10 en 2 Tessalonicenzen 2:1). Bovendien gaat het Paulus in deze passages primair niet om de eschatologie. De parousie is niet zijn onderwerp, maar het perspectief voor de paraklese die hij geeft.

Bij alle wezenlijke overeenkomst heeft de paraklese in de zogenoemde eschatologische gedeelten van 1 en 2 Tessalonicenzen telkens een andere spits. 1 Tessalonicenzen $4: 13-18$ is geschreven tot vertroosting en bemoediging met het oog op de ontslapenen; 5:1-11 is vooral een oproep tot waakzaamheid: om tot de dag des Heren te leven als kind van de dag. Beide gedeelten kennen tevens de oproep om met de paraklese 
die Paulus aan hen geeft, elkaar paraklese te geven. 2 Tessalonicenzen 1:5-10 en 2:1-12 hebben als doel de gemeente in de verdrukkingen te bemoedigen. Ze zijn bedoeld als een aansporing te blijven volharden. Al zijn de tijden zwaar en zullen ze nog zwaarder worden, bij de parousie zal het lijden overgaan in heerlijkheid.

De conclusie luidt dat de overeenkomsten groter zijn dan de verschillen. Dat blijkt hierin dat er ook in de verschillen overeenkomsten zijn. Bovendien is er op twee hoofdpunten overeenkomst. De (overeenkomst in de) verschillen en de overeenkomsten in doelstelling tussen 1 en 2 Tessalonicenzen zijn als volgt samen te vatten:

- In 1 Tessalonicenzen 1-3 komt uitvoerig de innige band tussen de auteur en de gemeente ter sprake om die te versterken. In 2 Tessalonicenzen gebeurt dat slechts indirect.

- 1 Tessalonicenzen bevat een nadrukkelijk appèl tot een heilig leven. Dat gebeurt in 2 Tessalonicenzen slechts heel beknopt.

- In 1 Tessalonicenzen 4:11-12 en 5:14 worden zij die zich ongeregeld gedroegen, beknopt vermaand. Dat gebeurt in 2 Tessalonicenzen 3:612 uitvoerig en scherp.

De overeenkomsten in doelstelling zijn belangrijker. Ze kunnen als volgt worden samengevat:

- Dank aan God voor het geloof, de liefde en de hoop van de Tessalonicenzen.

- Paraklese in het perspectief van de parousie.

Paulus schreef 1 en 2 Tessalonicenzen omdat hij zelf niet tot de gemeente kon komen. Hij deed dat met het doel hun te laten weten hoe dankbaar hij God was dat zij op de weg van het geloof staande waren gebleven. Hij vuurt hen aan op die weg te blijven wandelen. Hij bemoedigt, vertroost en vermaant hen. Die paraklese geeft hij met het uitzicht op de parousie, de dag waarop alle gelovigen samen voor altijd met de Here zullen zijn.

\section{Bibliog rafie}

BAARDA, T. 1984. "Maar de toorn is over hen gekomen ...". (In Baarda, T., red. Paulus en de andere joden. Delft : Meinema. p. 15-74.)

BAILEY, J.A. 1978/79. Who wrote 2 Thessalonians? New Testament Studies, 25:131-145.

BEST, E. 1972. A commentary on the First and Second Epistles to the Thessalonians. London : Black.

BJERKELUND, C.J. 1967. Parakalô: Form, Funktion und Sinn der Parakalô-Sätze in den paulinischen Briefen. Oslo : Universiteitsforlaget. 
BOERS, H. 1975-76. The form-critical study of Paul's Letters: 1 Thessalonians as a case study. New Testament Studies, 22:140-158.

BOLKESTEIN, M.H. 1974. De brieven aan de Tessalonicenzen. Nijkerk : Callenbach.

BOTHA, J. \& JANSE VAN RENSBURG, F.J. 1993. "Paranese" of "paraklese" as generiese terme vir Nuwe-Testamentiese "moral exhortation"? In die Skriflig, 27(1):29-51.

BRUCE, F.F. 1982. 1 \& 2 Thessalonians. Waco, TX : Word.

CORNELIUS, E.M. 1998. The effectiveness of 1 Thessalonians - A rhetorical-critical study. Stellenbosch : University of Stellenbosch. (Ph.D. Dissertation.)

DE BOOR, W. 1975. Die Briefe des Paulus an die Thessalonicher. Wuppertal : Brockhaus.

DU PREEZ, J. 1981. Die Briewe aan die Tessalonisense. Kaapstad: NG KerkUitgewers.

ERLEMANN, K. 1995. Naherwartung und Parusieverzögerung im Neuen Testament. Ein Beitrag zur Frage religiöser Zeiterfahrung. Tübingen : Francke.

FIJNVANDRAAT, J.G. \& MEDEMA, H.P. 1992. Zo zullen wij altijd met de Heer zijn. Over de komst van Christus en de opname van de gemeente. Vaassen : Medema.

GIBLIN, C.H. 1967. The threat to faith. An exegetical and theological re-examination of 2 Thessalonians 2. Rome : Pontifical Biblical Institute.

HOFFMANN, P. 1966. Die Toten in Christus. Eine religionsgeschichtliche und exegetische Untersuchung zur paulinischen Eschatologie. Münster : Aschendorf.

HOLMES, M.W. 1998. 1 and 2 Thessalonians. The NIV Application Commentary. Grand Rapids, Michigan : Zondervan.

HOLTZ, T. 1990. Der erste Brief an die Thessalonicher. Zürich : Benzinger.

HUGHES, F.W. 1989. Early Christian rhetoric and 2 Thessalonians. Sheffield : JSOT.

JOHANSON, B.C. 1987. To all the brethern: A text-linguistic and rhetorical approach to 1 Thessalonians. Stockholm : Almqvist \& Wiksell.

KRAMER, G.H. 1992. De verschijning van Zijn komst. Bijbelstudie over de Tweede Brief van Paulus aan de Thessalonikers. Vaassen : Medema.

LAMBRECHT, J. 2000. Thanksgivings in 1 Thessalonians 1-3. (In Donfried, K.P. \& Beutler, J., ed. The Thessalonian debate. Methodological discord or methodological synthesis? Grand Rapids, Michigan : Eerdmans. p. 135-163.)

LÖVESTAM, E. 1963. Spiritual wakefulness in the New Testament. Lund : Gleerup.

MALHERBE, A. 2000. The Letters to the Thessalonians. New York: The Anchor Bible Doubleday.

MARXSEN, W. 1979. Der erste Brief an die Thessalonicher. Zürich : Theologischer Verlag.

MARXSEN, W. 1982. Der zweite Brief an die Thessalonicher. Zürich : Theologischer Verlag.

MENKEN, M.J.J. 1994. 2 Thessalonians. London/New York : Routledge.

O'BRIEN, P.T. 1977. Introductory thanksgivings in the Letters of Paul. Leiden : Brill.

RICHARD, E.J. 1995. First and Second Thessalonians. Collegeville, MN : Liturgical Press.

ROOSEN, A. 1971. De brieven van Paulus aan de Tessalonicenzen. Roermond : Romen.

SCHUBERT, P. 1939. Form and function of the Pauline thanksgivings. Berlin : Töpelmann.

SMITH, A. 1990. The social and ethical implications of the Pauline rhetoric in 1 Thessalonians. Nashville, TN : Vanderbilt University. (Ph.D. Dissertation.) 
SMITH, A. 1995. Comfort one another. Reconstructing the rhetoric and audience of 1 Thessalonians. Louisville : Westminster John Knox.

TRILLING, W. 1980. Der zweite Brief an die Thessalonicher. Zürich : Benzinger.

VERHOEF, E. 1998. De brieven aan de Tessalonicenzen. Kampen : Kok.

VISSER, D. 1994. 'Samen leven met Hem'. De toekomstprediking in de brieven aan de Thessalonicenzen. Apeldoorn : Theologische Universiteit. (Hoofdvakscriptie N.T.)

VON DOBSCHÜTZ, E. 1909. Die Thessalonicherbriefe. Göttingen : Vandenhoeck \& Ruprecht.

WANAMAKER, C.A. 1990. Commentary on 1 and 2 Thessalonians. Grand Rapids, Michigan : Eerdmans.

WILES, G.P. 1974. Paul's intercessory prayers: The significance of the intercessory prayer passages in the Letters of St. Paul. Cambridge : Cambridge University Press.

\section{Kernbegrippen:}

paraklese $-1 \& 2$ Tess.

parousie $-1 \& 2$ Tess.

Tessalonicenzen (1); doel van

Tessalonicenzen (2); doel van

\section{Key concepts:}

paraclesis $-1 \& 2$ Thess.

parousia $-1 \& 2$ Thess.

Thessalonians (1); purpose of

Thessalonians (2); purpose of 
